\title{
Estimating Impact of Covid 19 Outbreaks on Regional Economic's Development
}

\author{
Sambari Radianto ${ }^{1}$, Mahjudin ${ }^{2}$ \\ ${ }^{1}$ Program Studi Magister Manajemen Universitas Muhammadiyah Gresik \\ ${ }^{2}$ Program Studi Magister Manajemen Universitas Muhammadiyah Gresik \\ sh.radianto@umg.ac.id
}

\begin{abstract}
Indonesia officially declared the first case of the corona virus infection that caused Covid-19 in early March 2020. Since then, various counter measures have been taken by the government to reduce the impact of the Covid-19 outbreaks in various sectors. Restrictions on community activities affect business activities which led to economics declination. Almost all sectors are affected.

This study aims to estimate the impact of the COVID-19 outbreaks on the regional economics development. This research using composite index to estimate the impact of the COVID-19 outbreaks on the regional economic develompment and this was carried out by building an index composite showing the severity of health on one hand and economic performance on the other.

This research shows, 34 provinces in Indonesia can be classified into four quadrants: 1) health improving and the economy is improving, 2) health is improving and the economy is deteriorating, 3 ) health worsening and the economy is improving, and 4) health is deteriorating and the economy is deteriorating. This study aprovide suggestions in order to be more accurate in identifying problems and finding precise solutions, the local government should collect data and research on economic aspects in a fast and precise way, namely 1) the level of the COVID-19 outbreak in the province, 2 ) risk factors for natural disasters, 3), factors characteristic of economic problems, 4) fiscal burden factors.
\end{abstract}

Keyword : Covid 19 outbreaks, economic development, economics crisis, regional economics

\section{Introduction}

On March 15th, 2020, the first Indonesian cases of the novel coronavirus were published in the WHO's fifth report [1]. When the outbreak hit Indonesia, Java Island which is one of the biggest island in Indonesia has severe damage from COVID-19 pandemies compare to other island. Given that COVID-19 has not passed until now, questions arise that must be answered: what and how will the impact of COVID-19 on the Indonesian economy, both nationally and sub-nationally. Various parties have made efforts to answer this question, both to estimate the impact of the COVID-19 outbreak on the national economy as well as at the sub-national level.

Calculation on the economic impacts of covid 19 oubreak at a national level was carried out many researcher, some of them are Dito Adidharma [2] and Yusuf [3] . Using computable general 
equilibrium model, Yusuf simulates three scenarios (minimal intervention against COVID-19, PSBB/strong intervention, and PSBB accompanied by fiscal stimulus) and estimates of their respective impacts on economic growth. The simulation results found that in any scenario, the national economy will experience a decline towards the baseline (if the Covid 19 didn't exist) with a number of decreases, from minus 0.11 to minus 4.21 percentage points (percentage difference from baseline). Furthermore, the simulation shows that in the long term (in the next decade), economic growth will be more depressed if the scenario chosen is minimal intervention. Accordingly, the calculations indicate that the economic losses from the Large-Scale Social Restrictions (Pembatasan Sosial Berskala Besar) are much lower than the economic losses from the minimal intervention scenario[4], and of course the PSBB accompanied by fiscal stimulus is the best scenario according to these simulations and calculations.

Another example of analysis at the national level with different methods is the regression analysis of the impact of economic contraction on poverty, as was done by Suryahadi, Al Izzati, \& Suryadarma [5]. It is estimated that the poverty rate, which was in the range of 9.2 percent (September 2019), will become 9.7 percent by the end of 2020 . This is equivalent to the emergence of only 1.3 million poor people. In fact, in the worst case scenario, poverty increases to $12.4 \%$, which is equivalent to 8.5 million new poor people.

Suryahadi [5] carried out at the sub-national level, using a fast indicator (relative to standard macroeconomic data, which time lagging can reach a year) as proxies to economic indicators, namely movement data of Facebook users recorded in the Facebook range map. Mobility is assumed to be a good proxy because it is a very important part of economic activity, which shows the movement to the center of activity, the movement of goods, and shopping activities. It is assumed that the higher the mobility, the higher the economic activity.

Analysis of the impact of the COVID-19 oubreaks on the economy is carried out by building a composite index that shows the severity of health on the one hand and economic performance on the other [6]. As a result, 34 provinces in Indonesia can be classified into four quadrants: 1) health is improving and the economy is improving, 2) health is improving and the economy is deteriorating, 3 ) health is deteriorating and the economy is improving, and 4) health is getting worse and the economy is deteriorating. The three timelines used were August (baseline) and October 29 (endline); the condition for better or worse is done by comparing the conditions in the three timelines.

With the results of previous studies, this paper tries to complement with a focus on the sub-national level, namely the province. To solve this problem, three interrelated questions were raised: 1) how widespread and what is the trend of the spread of COVID-19 in each province in Indonesia? 2) what is the estimated impact on the province economy? and 3) what are the possible economic policies to reduce the impact of the outbreak in each of these provinces? This research will try to present descriptive answers by maximizing the use of data at province level.

\section{Methods}

This research utilize descriptives methods to measure the economics impact of COVID-19 in Indonesia and rely on a simple model with several accompanying assumptions. This simple model assumes that the severity impact of COVID-19 on the province economy (OI) is determined by four factors that simultaneously work in the regions, namely the outbrteaks level (PL), potetial risk for natural disasters (ND), poverties level (PoL), and fiscal's pressure (FC). So we can assumed thaht bigger PL, ND, PoL, and FC the bigger OI.

The level of the COVID-19 outbreaks (OI) is measured by a modification of the variable, namely the ratio of cured cases to the ratio of infected cases, which we call the variable PL. We calculated the modification of PL varable is at the provincial level instead of the island cluster, and in addition, because of the variation in the PL value from time to time, we used PL based on three months (throughout August and October 2020) or the last 92 days of observation. We considered the last three months of observation because at the beginning of the outbreak the province health institutional system was assumed not ready yet to face the COVID-19 outbreak. But within last three months it has worked properly so that the initial value in that period relatively reflects the real capacity of the health system. The higher the PL the higher the OI (the economic impact of COVID-19 in one province).

Natural disaster risk factor (ND) is a factor that will affect an area's ability to resist pressure. Imagine if an area experiences a natural disaster at the same time as the COVID-19 outbreak, the 
pressure will multiply.Thus, in this model, the more an area has a high risk factor for disaster, the higher the economic impact it will experience. In this research, disaster risk factors are measured with the latest data collected in the 2020 natural disaster survey [7].

The factor of provincies poverties (PoL) in this research will use poverties information from BPS data on 2019 sensus for this article purposes [8]. The higher the poverty level before the COVID-19 outbreak, the heavier the economic impact of COVID-19 in the provincies. Because simultaneously the number of poor people will increase with the new poor.

The fiscal pressure factor $(F)$ is measured by actual provincies income per capita which in this paper is generated from total province's actual income and then divided by the number of provincial residents. Provincies actual income per capita demonstrates a region's ability to use its budget resources to tackle COVID-19, for example to provide financial assistance and subsidies to the community. Actual province's income per capita was chosen as an indicator because it shows the relative financial capacity of each region independent of financial transfers from the center[2].

\section{Results}

Composite index calculation in use for this research is the first iteration on varimax rotation using SPSS V.23. The calculation without weighting all variables so they are considered to have the same weight. Of course this is another simplification of the model and the calculation results presented in this paper. With a note about the limitations of the model and the process of calculating the composite index, the results are shown in table 1

Tabel 1. Tabulasi Perhitungan Composite Index

\begin{tabular}{c|l|c|c|c|c|c|} 
No & \multicolumn{1}{|c|}{ Provinces } & $\mathrm{PL}$ & $\mathrm{ND}$ & $\mathrm{PoL}$ & $\mathrm{Fc}$ & $\mathrm{Dl}$ \\
\hline 1 & Papua & 0,4253 & 0,058 & 0,0447 & 0,2765 & 0.6610 \\
\hline 2 & Kepulauan Bangka Belitung & 0,0446 & 0,001 & 0,0306 & 0,3031 & 0.6689 \\
\hline 3 & Daerah Istimewa Yogyakarta & 0,0231 & & 0,1153 & 0,3121 & 0.6625 \\
\hline 4 & Aceh & 0,0180 & & 0,0984 & 0,1853 & 0.4757 \\
\hline 5 & JawaBarat & 0,0052 & 0,029 & 0,0714 & 0,3476 & 0.6824 \\
\hline 6 & Sulawesi Utara & $-0,0231$ & 0,006 & 0,0522 & 0,3071 & 0.7079 \\
\hline 7 & Sulawesi Selatan & $-0,0325$ & 0,113 & 0,0449 & 0,3271 & 0.7135 \\
\hline 8 & Kalimantan Selatan & $-0,0508$ & 0,009 & 0,0361 & 0,3106 & 0.7079 \\
\hline 9 & Sumatera Barat & $-0,0596$ & 0,015 & 0,0497 & 0,3207 & 0.7022 \\
\hline 10 & Kalimantan Timur & $-0,0630$ & 0,026 & 0,0445 & 0,1688 & 0.4674 \\
\hline 11 & Jakarta & $-0,0689$ & 0,001 & 0,0453 & 0,2547 & 0.6592 \\
\hline 12 & Jawa Tengah & $-0,0747$ & 0,100 & 0,1009 & 0,3466 & 0.6678 \\
\hline 13 & Jawa Timur & $-0,0804$ & 0,101 & 0,0789 & 0,3412 & 0.8871 \\
\hline 14 & Riau & $-0,1661$ & 0,018 & 0,0612 & 0,2206 & 0.4933 \\
\hline 15 & Sumatera Utara & $-0,1815$ & 0,006 & 0,0873 & 0,3294 & 0.6757 \\
\hline 16 & Kalimantan Tengah & $-0,1884$ & 0,029 & 0,0462 & 0,2427 & 0.4850 \\
\hline 17 & Bali & $-0,1931$ & 0,016 & 0,0333 & 0,2127 & 0.4429 \\
\hline 18 & Banten & $-0,2507$ & 0,006 & 0,0503 & 0,2358 & 0.6891 \\
\hline 19 & Lampung & $-0,5207$ & 0,003 & 0,0902 & 0,2472 & 0.5618 \\
\hline 20 & Jambi & $-0,6376$ & 0,005 & 0,1041 & 0,3200 & 0.7618 \\
\hline 21 & Kepulauan Riau & $-0,6625$ & 0,000 & 0,0542 & 0,2103 & 0.5022 \\
\hline 22 & SulawesiBarat & $-0,6903$ & 0,002 & 0,0959 & 0,3339 & 0.8122 \\
\hline 23 & Kalimantan Barat & $-0,7224$ & 0,010 & 0,0469 & 0,3061 & 0.6067 \\
\hline 24 & Sulawesi Tengah & $-0,7416$ & 0,008 & 0,0876 & 0,3174 & 0.8919 \\
\hline 25 & Bengkulu & $-0,7666$ & 0,024 & 0,1477 & 0,3066 & 0.8910 \\
\hline 26 & Sulawesi Tenggara & $-0,7940$ & & 0,0714 & 0,3123 & 0.5474 \\
\hline 27 & Sumatera Selatan & $-0,8149$ & & 0,1216 & 0,3269 & 0.5130 \\
\hline 28 & Nusa TenggaraBarat & $-0,8206$ & 0,126 & 0,149 & 0,3314 & 0.8674 \\
\hline 29 & Nusa Tenggara Timur & $-0,7406$ & 0,210 & 0,166 & 0,3334 & 0.8730 \\
\hline 30 & Papua Barat & $-0,8529$ & & 0,0585 & 0,2126 & 0.4730 \\
\hline 31 & Maluku & $-0,8542$ & 0,073 & 0,0623 & 0,3074 & 0.8730 \\
\hline 32 & Maluku Utara & $-0,8554$ & 0,014 & 0,0453 & 0,2992 & 0.8730 \\
\hline 33 & Kalimantan Utara & $-0,8642$ & 0,000 & 0,0506 & 0,2772 & 0.5730 \\
\hline 34 & Gorontalo & $-0,9466$ & 0,002 & 0,0397 & 0,2114 & 0.6674 \\
\hline
\end{tabular}

From table 1, it can be seen that there are three classifications of economic severity due to COVID-19 
that are estimated to be experienced by each regions, which has severity impact of COVID-19 (OI) value higher than 0.60 indicating high outbreak level (worst condition), the OI value ranges from 0.50 0.60 indicating middle conditions, and the OI value below 0.50 confirming those regions have low outbreak level. The region like wise Jawa Tengah, Jawa Timur, Sulawesi Utara, Sulawesi Selatan, Kalimantan Selatan, Sumatera Barat, Sulawesi Tengah, Bengkulu are amongs the provincies being predicted will get worst economic impact from COVID-19 outbreaks, so from these like regions an intense solutions should be prepared by provincies goverments to overcome and anticipate these impacts.

\section{Suggested Policies Framework}

The descriptive analysis carried out in previous section, contains limitations on economic standard data which does not allow the regions to validly produce concrete policy prescriptions that can be carried out. Even econometric analysis and computable general equilibrium also have limitations in terms of the novelty of the data used and the level which is still the national aggregate or the most detailed provincial level. Macroeconomic data as well as survey data at the household level have a fairly long lag, between data collection and data ready-to-use.

From an economic point of view, the COVID-19 outbreak that has been occurring since early 2020 in all countries in the world, is called a non-economic event that has a shocking effect on the economy. The economy is under pressure (shock) both from the production side (supply side) and demand (demand side). The supply side is depressed / reduced / stopped due to concerns about health risks if the goods and services production process is carried out (factories, offices, restaurants, hotels, etc. are closed). The direct result is the loss of people's jobs (new unemployment appears) as has been recorded in the rapid assessment, which in turn reduces their purchasing power. Declining purchasing power has even resulted in a decrease in consumption for basic food needs or what is called food insecurity in the discussion in the previous section. Furthermore, those who live in urban areas or in locations where renting housing and living costs are more expensive are forced to do temporary migration as identified in the rapid assessment[9].

\section{Discussion}

This paper departs from a simple model which assumes that the severity of the impact of COVID-19 on the province's's economy (OI) is determined by four factors that simultaneously work in the each provincies, namely: the level of the COVID-19 outbreak in the provincies (PL), potential risk for natural disasters (ND), the poverties level (PoL), and the

fiscal distress factor (FC). Even though it has limitations, it is hoped that the information generated will be useful, especially for local governments, that the scale of economic problems due to COVID19 will be even greater if the outbreak continues and regions have various other problems such as these variables. This simple model can even be made more complete with other variables, for example the morbidity rate or prevalence of other infectious diseases in the provincies, and other relevant variables [10].

In order to more accurately identify problems and find solutions that can be done, local governments should collect data and research on economic aspects in a fast and precise manner, as exemplified in the references referred to in this paper. Relying on traditional data that has a long time-lagging time can result in delays in policy implementation or even misdirection as was found in some cases during this outbreak.

\section{Conclusion}

The COVID-19 pandemic situation provides both a challenge and an opportunity for the government to maintain the existence of business actors as the spearhead of the economy. Challenges are defined as the need for short-term solutions to help business actors and their workers.. Opportunity means that short-term solutions need to be followed by long-term solutions, especially when it is related to the industrial era 4.0 which requires the availability of digital technology to support economic activity. There are several solutions that need to be considered, namely: strict health protocols in carrying out economic activities by business actors, delaying debt or credit payments to maintain financial liquidity, financial assistance for business actors, and structural policies.

Firstly, strict health protocols can be applied when the government gives permission for businesses to 
carry out their activities. The mandatory use of masks, gloves and a safe distance between workers can be a requirement for continuing to carry out their activities. Of course there needs to be cooperation from business actors and close supervision from the competent authorities so that this health protocol can run well. In this context, the government can involve civil servants at the village office in monitoring the implementation of health protocols for business actors who are allowed to carry out their activities.

Second, the government can issue policies to provide concessional debt or credit repayments for business actors or even postpone the payment process for up to six months by considering financial liquidity. This includes simplifying the administrative process for obtaining a loan in the midst of this emergency situation. This can be done so that business actors including workers can maintain the level of consumption and purchasing power while at the same time supporting the running of the national economy.

Third, financial assistance to business actors. The Indonesian government has disbursed a budget of Rp. 70.1 trillion for tax incentives and stimulus for business actors' credit from the total budget of Rp. 405.1 trillion overcoming the Covid-19 pandemic through the 2020 State Budget. The distribution of this budget must be transparent, clear, and on target so that the existence of local business and real economic activities is maintained.

Fourth, structural policies for long-term interests. This policy is not only used to deal with the COVID-19 pandemic but also the Industrial 4.0 era in the future. This policy includes short-term policies for business actors, namely the introduction of digital technology and training for business actors and their workers as well as long-term policies for businesses to adapt to the use of technology for production processes, use of digital technology media to promote their products.

\section{REFERENCES}

[1] WHO Indonesia, "Coronavirus Disease Situation Report World Health Organization," World Heal. Organ., vol. 19, no. May, pp. 1-17, 2020.

[2] D. A. D. Nasution, E. Erlina, and I. Muda, "Dampak Pandemi COVID-19 terhadap Perekonomian Indonesia," J. Benefita, vol. 5, no. 2, p. 212, 2020, doi: 10.22216/jbe.v5i2.5313.

[3] A. A. Yusuf, "Mengukur ongkos ekonomi 'sesungguhnya' dari pandemi Covid-19," SDG's Cent. Univ. Padjajaran, no. 1, p. 14, 2020.

[4] C.- Implikasi and B. Usaha, "Covid-19 Dan Implikasi Bagi Usaha Mikro, Kecil, Dan Menengah," J. Ilm. Hub. Int., vol. 0, no. 0, pp. 59-64, 2020, doi: 10.26593/jihi.v0i0.3870.59-64.

[5] A. Suryahadi, R. Al Izzati, and D. Suryadarma, "The Impact of COVID-19 Outbreak on Poverty: An Estimation for Indonesia (Draft)," SMERU Work. Pap., vol. April, pp. 1-20, 2020.

[6] R. Chetty, J. N. Friedman, N. Hendren, and M. Stepner, "Introduction,” 2020.

[7] Badan Pusat Statistik, "Jumlah Korban yang Diakibatkan Bencana Alam Menurut Provinsi, 2019," Sosial dan Kesejahteraan Rakyat. p. 1, 2020.

[8] BPS, "Penduduk, Laju Pertumbuhan Penduduk, Distribusi Persentase Penduduk, Kepadatan Penduduk, dan Rasio Jenis Kelamin Penduduk Menurut Provinsi, 2019," BPS (Badan Pusat Statistik). 2019.

[9] E. Budiyanti, "Dampak Virus Corona Terhadap Sektor Perdagangan Dan Pariwisata Indonesia," Kaji. Bid. Ekon. Dan Kebijak. Publik, vol. XII, no. 4, pp. 19-24, 2020.

[10]https://www.bps.go.id/publication/2020/06/01/effd7bb05be2884fa460f160/tinjauan-big-dataterhadap-dampak-covid-19-2020.html 